\title{
Diagnostic Value of Procalcitonin in Predicting Bacteremia in Intensive Care Unit
}

Sir,

We read with great interest the article by Demirdal et al.$^{[1]}$ titled, "Diagnostic Value of Procalcitonin in Predicting Bacteremia in Intensive Care Unit." We appreciate this article. The authors have compared very well the utility of procalcitonin (PCT) in differentiating bacteremic and nonbacteremic patients and between Gram-positive bacteremia and Gram-negative bacteremia.

We would like to pose a few comments regarding this study to the authors:

Levels of PCT cited in the article are described in ng/dl unit (most of the articles till date have described PCT as ng/ $\mathrm{ml}$ or $\mu \mathrm{g} / \mathrm{l}$ both being the same). ${ }^{[2]}$ If we convert the value of PCT described in $\mathrm{ng} / \mathrm{dl}$ to $\mathrm{ng} / \mathrm{ml}$, the value will be less than the range of PCT described in existing literature $(1 \mathrm{ng} /$ $\mathrm{dl}=0.01 \mathrm{ng} / \mathrm{ml}$ ). The authors have described in the discussion of this article that Leli et al. ${ }^{[3]}$ demonstrated that average level of PCT was $13.8 \mathrm{ng} / \mathrm{ml}$ in Gram-negative bacteremia and $2.1 \mathrm{ng} / \mathrm{ml}$ in Gram-positive bacteremia. Although the authors have described that they got the higher levels of PCT in Gram-negative bacteria, they described PCT value in $\mathrm{ng} / \mathrm{dl}$

Standard deviation for PCT values sited in Table 1 is very high. Hence, it is advisable to exclude the extreme values while analyzing the data

PCT was measured only once within first $24 \mathrm{~h}$ of Intensive Care Unit (ICU) admission. Serial levels were not measured and not correlated with the severity of sepsis during the course of ICU stay. Studies suggest that serial measurement of PCT predict outcome during ICU stay ${ }^{[4]}$

The authors have sited that out of 92 nonbacteremic patients (culture negative), 17 had systemic inflammatory response syndrome (SIRS), 34 had sepsis, and 41 had severe sepsis/septic shock. The authors have not described the cause of sepsis and septic shock in nonbacteremic group. Moreover, out of the 17 patients with SIRS in the nonbacteremic group, $7(41.1 \%)$ patients had mortality which is quite high. The authors have not specified the cause of mortality in patients with SIRS

The authors have pointed out that overall mortality is comparable between bacteremic and nonbacteremic group $(P=0.418)$. However, twenty-eight day mortality was higher in the nonbacteremic group than patients with bacteremia
$(P=0.002)$. Twenty-eight day mortality was higher in the nonbacteremic group than patients with bacteremia $(P=0.002)$. In the discussion, the authors have not described the causes of higher 28-day mortality in the nonbacteremic group.

\section{Financial support and sponsorship}

Nil.

Conflicts of interest

There are no conflicts of interest.

Rupali Patnaik, Afzal Azim

Department of Critical Care Medicine, SGPGIMS, Lucknow, Uttar Pradesh, India

Address for correspondence: Dr. Afzal Azim, Department of Critical Care Medicine, SGPGIMS, Lucknow - 226014 ,

Uttar Pradesh, India.

E-mail: draazim2002@gmail.com

\section{RefERENCES}

1. Demirdal T, Sen P, Nemil SA. Diagnostic value of procalcitonin in predicting bacteremia in Intensive Care Unit. Indian J Crit Care Med 2018;22:78-84.

2. Carr JA. Procalcitonin-guided antibiotic therapy for septic patients in the surgical Intensive Care Unit. J Intensive Care 2015;3:36.

3. Leli C, Ferranti M, Moretti A, Al Dhahab ZS, Cenci E, Mencacci A, et al. Procalcitonin levels in gram-positive, gram-negative, and fungal blood stream infections. Dis Markers 2015;2015:701480.

4. Schuetz P, Birkhahn R, Sherwin R, Jones AE, Singer A, Kline JA, et al. Serial procalcitonin predicts mortality in severe sepsis patients: Results from the Multicenter Procalcitonin Monitoring Sepsis (MOSES) study. Crit Care Med 2017;45:781-9.

This is an open access journal, and articles are distributed under the terms of the Creative Commons Attribution-NonCommercial-ShareAlike 4.0 License, which allows others to remix, tweak, and build upon the work non-commercially, as long as appropriate credit is given and the new creations are licensed under the identical terms.

\begin{tabular}{|l|l|}
\hline \multicolumn{2}{|c|}{ Access this article online } \\
\hline Quick Response Code: & Website: \\
\hline & www.ijccm.org \\
\hline
\end{tabular}

How to cite this article: Patnaik R, Azim A. Diagnostic value of procalcitonin in predicting bacteremia in Intensive Care Unit. Indian J Crit Care Med 2018;22:389.

C 2018 Indian Journal of Critical Care Medicine | Published by Wolters Kluwer - Medknow 